\title{
DA APLICABILIDADE DO INCIDENTE DE DESLOCAMENTO DE COMPETÊNCIA
}

\author{
José Gabriel Pontes Baeta da Costa ${ }^{291}$
}

Recebido em: 03/08/2016

Aprovado em: 23/09/2016

\begin{abstract}
RESUMO
A Emenda Constitucional $n^{\circ}$. 45/04 criou um novo instituto jurídico, chamado de incidente de deslocamento de competência, aplicável nas hipóteses de graves violações aos direitos humanos, ensejando a transferência do inquérito ou da ação judicial às instâncias federais. Esta criação levou a grandes discussões doutrinárias, em função de uma aparente violação a alguns princípios constitucionais, como o juiz natural, o contraditório, a ampla defesa, o pacto federativo e a segurança jurídica. $\mathrm{O}$ escopo do presente artigo foi o de ponderar sobre a constitucionalidade do incidente de deslocamento de competência, adequando-o ao ordenamento jurídico pátrio através dos princípios da razoabilidade e da proporcionalidade, trazendo à tona algumas lições sobre os mecanismos internacionais de proteção aos direitos humanos e analogias à federalização através de casos concretos, como os incidentes suscitados até hoje, primando pela sua aplicabilidade no ordenamento jurídico pátrio.
\end{abstract}

Palavras-chave: Incidente. Deslocamento de competência. Direitos humanos. Federalismo. Princípios constitucionais. Cláusulas Pétreas. Proporcionalidade.

\section{INTRODUÇÃO}

A Emenda Constitucional no 45/04, comumente conhecida por "reforma do Judiciário", introduziu no ordenamento jurídico pátrio, dentre outros institutos, o Incidente de Deslocamento de Competência, representado pela sigla IDC.

Tal incidente se afigura através da interpretação extraída da norma contida no $\S 5^{\circ}$ do artigo 109 da Constituição Federal, o qual prevê a possibilidade de o Procurador-Geral da República suscitar perante o Superior Tribunal de Justiça, em qualquer fase do inquérito ou do

\footnotetext{
291 Graduado em Direito pela Pontifícia Universidade Católica de Minas Gerais. Pós-graduando em Direito Constitucional pela Rede Anhanguera-UNIDERP-LFG. Advogado. Endereço eletrônico: pontesbaeta@yahoo.com.br.
} 
processo, o aludido incidente de deslocamento de competência, com o fito de assegurar o cumprimento de obrigações decorrentes de tratados internacionais de direitos humanos dos quais o Brasil seja signatário.

O dispositivo legal em comento prevê, pois, a federalização dos crimes graves contra os direitos humanos, consistindo na possibilidade de deslocamento de competência da Justiça Comum para a Justiça Federal nas hipóteses em que houver configurada uma grave e clara violação de direitos humanos.

Impende ressaltar que para o deferimento do aludido deslocamento, faz-se necessário a comunhão de alguns requisitos objetivos, extraídos da redação do parágrafo $5^{\circ}$ do supracitado artigo 109, assim como a harmonização com os princípios constitucionais que tangenciam toda a atividade jurisdicional.

O presente estudo objetiva analisar a compatibilidade do Incidente de Deslocamento de Competência com a Constituição Federal, e, por consequência, com o ordenamento jurídico vigente.

Anote-se que o propósito não é esgotar as concepções teóricas acerca dos direitos humanos e/ou constitucionais, mas analisar o referido instituto à luz de uma hermenêutica constitucional que sufraga pela prevalência e defesa dos direitos humanos e pela harmonização e constitucionalidade da "Federalização" em comento.

Para tanto, utilizar-se-á da o método dedutivo, através do levantamento bibliográfico para fins de pesquisas, tendo como fonte primordial a doutrina brasileira, o direito estrangeiro comparado e a jurisprudência, assim como eventuais fontes necessárias para o bom desenvolvimento do tema abordado.

\section{DA FEDERALIZAÇÃO DOS CRIMES GRAVES CONTRA OS DIREITOS HUMANOS}

De maneira sucinta, importa aduzir que a referida federalização dos crimes graves contra os direitos humanos fora inserida no ordenamento jurídico vigente através da Emenda Constitucional $n^{\circ} .45 / 04$. Contudo, a previsão de julgamento de crimes em geral pela Justiça Federal, conforme previsto em tratados internacionais, remete-se à Constituição Federal de 1967.

Convém relembrar que o regime militar havia recriado a Justiça Federal através do Ato Institucional $\mathrm{n}^{\circ} 2$, promulgado em 1965 . Nesta esteira, o referido regime ditatorial apresentou 
um projeto para uma nova Constituição, através de um processo constituinte contestável, que resultou na aprovação da Carta Maior de 1967, cuja característica marcante era o controle sobre os atos do governo, atrasando as decisões judiciais em que ainda seriam aplicáveis as normas da Constituição de 1946 (SARLET, 2006, p. 39).

Passado uma década, veio a Emenda Constitucional n 7, data de 13 de abril de 1977, a qual incluía no artigo 125 o seguinte texto: "quando, iniciada a execução no País, o resultado tenha ou devesse ter ocorrido no estrangeiro, ou reciprocamente", conferindo à Justiça Federal a competência das hipóteses que posteriormente seriam previstas na Constituição de 1988.

Já no ano e 1996, fora editado o primeiro Plano Nacional de Direitos Humanos, sendo então, encaminhado ao Ministro da Justiça da época, Nelson Jobim, a primeira proposta de federalização os crimes contra os direitos humanos, através do Projeto de Emenda Constitucional $\mathrm{n}^{\mathrm{o}}$ 368-A de 13 de maio do corrente ano. Neste contexto, tal proposta fora apensada à Proposta e Emenda Constitucional no 96/92 que originou a Reforma do Judiciário, anos após. Com muitas discussões acaloradas, no ano de 2000 modificou-se o texto, o qual fora aprovado (SARLET, 2006, p. 39).

Posteriormente, fora aprovada a última redação pelo Senado, em primeiro turno, na data de 7 de julho de 2004, resultando na aprovação definitiva em plenário no dia 17 de novembro de 2004, sendo promulgada a Emenda Constitucional $n^{\circ} 45 / 04$ na data de 8 de dezembro de 2004 e publicada em 31 de dezembro do mesmo ano. ${ }^{292}$

Outrossim, cumpre anotar que a federalização dos crimes contra os direitos humanos não é única medida que transfere à seara federal uma competência que não lhe é originária. Sem adentrar em maiores discussões, fugindo do escopo principal deste estudo, importante apenas mencionar a Lei $n^{\circ}$ 10.446/02 que dispõe sobre as infrações penais de repercussão interestadual ou internacional, em atendimento ao artigo 144 da Constituição Federal ${ }^{293}$, atribuindo à Polícia

\footnotetext{
292 Art. 109 - Aos Juízes Federais compete processar e julgar:

$\mathrm{V}$ - os crimes previstos em tratado ou convenção internacional, quando iniciada a execução no País, o resultado tenha ou devesse ter ocorrido no estrangeiro, ou reciprocamente;

$\mathrm{V}-\mathrm{A}$ - as causas relativas a direitos humanos a que se refere o parágrafo quinto deste artigo;

$[\ldots]$

$\S 5^{\circ}$ - nas hipóteses de grave violação de direitos humanos, o Procurador-Geral da República, com a finalidade de assegurar o cumprimento de obrigações decorrentes de tratados internacionais de direitos humanos, dos quais o Brasil seja parte, poderá suscitar, perante o Superior Tribunal de Justiça, em qualquer fase do inquérito ou processo, o incidente de deslocamento e competência para a Justiça Federal).

${ }^{293}$ Art. $1^{\circ}$ - Na forma do inciso I do $\S 1^{\circ}$ do art. 144 da Constituição, quando houver repercussão interestadual ou internacional eu exija repressão uniforme, poderá o Departamento de Polícia Federal do Ministério da Justiça, sem prejuízo da responsabilidade dos órgãos de segurança pública arrolados no art. 144 da Constituição Federal, em especial das Polícias Militares e Civis dos estados, proceder à investigação, dentre outras, das seguintes infrações penais: 
Federal a competência para proceder com a investigação, independente da responsabilidade dos órgãos de segurança do Estado (BONAVIDES, 2010, p. 523).

Urge destacar, pois, que o incidente de deslocamento de competência representa apenas uma das medidas possíveis de transferência da competência estadual para a federal. Destarte, seus requisitos e pressupostos que o diferenciam dos demais instrumentos serão adiante sublinhados.

\section{REQUISITOS E PRESSUPOSTOS PARA O DESLOCAMENTO DE COMPETÊNCIA}

A norma contida no artigo 109 , inciso $\mathrm{V}$ e em seu $\S 5^{\circ}$, é apta e clara a demonstrar como tem início o procedimento de deslocamento de competência, deixando implícito que não compete ao Procurador-Geral da República emitir qualquer decisão acerca do cabimento ou não da medida pleiteada. Para este, caberá apenas a análise dos pressupostos constitucionais que dão azo à propositura do deslocamento em cotejo. ${ }^{294}$

Da leitura das normas supracitadas, infere-se que a prerrogativa de federalização em comento enseja a conjugação de três requisitos básicos, sendo eles: a existência de uma grave violação aos direitos humanos, a necessidade de assegurar o cumprimento de tratado internacional do qual o Brasil seja signatário e a inépcia ou incapacidade das autoridades originariamente competentes para responder ao caso específico. Analisemos, pois, os requisitos em cotejo.

\section{EXISTÊNCIA DE GRAVE VIOLAÇÃO AOS DIREITOS HUMANOS}

\footnotetext{
III - relativas à violação a direitos humanos, que a República Federativa do Brasil se comprometeu a reprimir em decorrência de tratados internacionais de que seja parte; [...]

${ }^{294}$ Art. 109 - Aos juízes federais compete processar e julgar:

$[\ldots]$

$\mathrm{V}$-A as causas relativas a direitos humanos a que se refere o $\S 5^{\circ}$ deste artigo.

$[\ldots]$

$\S 5^{\circ}$ Nas hipóteses de grave violação de direitos humanos, o Procurador-Geral da República, com a finalidade de assegurar o cumprimento de obrigações decorrentes de tratados internacionais de direitos humanos dos quais o Brasil seja parte, poderá suscitar, perante o Superior Tribunal de Justiça, em qualquer fase do inquérito ou processo, incidente de deslocamento de competência para a Justiça Federal.
} 
De plano, impende mencionar que não se trata de qualquer violação aos direitos humanos, mas sim, de grave violação. Nesta seara, surge uma acalorada discussão doutrinária do conceito exato do que seriam as "graves violações" aduzidas.

Destarte, o exato conteúdo da expressão "direitos humanos" também suscita grande debate, vez que o legislador transferiu a responsabilidade de conceituar tais temas para a doutrina e a jurisprudência. Anote-se que o presente estudo não busca esgotar tais questões, objetivando apenas descrever um cenário propício para adentrar nos argumentos favoráveis e contrários ao instituto em análise.

Acerca da gravidade das lesões ou violações, em que pese o silêncio do legislador, é grande a contribuição da doutrina e do direito comparado para que se configurem tais violações. Assim, destaca-se que se trata de um conceito jurídico indeterminado, traço característico dos textos constitucionais contemporâneos, o que não inviabiliza a aplicação do preceito constitucional, mas enseja uma análise hermenêutica mais aprofundada.

A indeterminação de conceitos é uma técnica que visa evitar o engessamento do ordenamento jurídico, conferindo a necessária permeabilidade, se afigurando como expressões propositalmente vagas que são utilizadas pragmaticamente pelo legislador, com o fito de propiciar o ajuste de certas normas a uma realidade cambiante ou ainda pouco conhecida. (FARIA, 1993, p. 139)

O Superior Tribunal de Justiça ao julgar o Incidente de Deslocamento de Competência IDC-1, sufragou como adequada a não definição de um rol taxativo do que seriam graves violações, permitindo a flexibilização da norma diante do caso concreto, in verbis:

Dada a amplitude e a magnitude da expressão "direitos humanos", é verossímil que o constituinte derivado tenha optado por não definir um rol dos crimes que passaram para a competência da Justiça Federal, sob pena de restringir os casos de incidência do dispositivo ( $\mathrm{CF}$, art. $109, \S 5^{\circ}$ ), afastando-o de sua finalidade precípua, que é assegurar o cumprimento de obrigações decorrentes de tratados internacionais firmados pelo Brasil sobre a matéria, examinando-se cada situação de fato, suas circunstancias e peculiaridades detidamente, motivo pelo qual não há de se falar em norma de eficácia limitada. Ademais não é próprio de texto constitucional tais definições (BRASIL, 2005, p. 217).

Pelas palavras do relator, um rol exemplificativo dos crimes considerados como graves violações poderia criar uma banalização do instituto da federalização, fugindo do princípio básico do texto constitucional. Assim, cada caso deve ser analisado sob o prisma dos princípios constitucionais da razoabilidade e da proporcionalidade. 
Não obstante, o Superior Tribunal de Justiça ao julgar o "caso Manoel Mattos" 295 (IDC2) decidiu que é de responsabilidade do referido órgão examinar o caso concreto, observando a razoabilidade e a proporcionalidade da medida, dando efetividade ao deslocamento de competência, superando a subjetividade legislativa do mesmo.

Para o doutrinador Eugênio Pacelli de Oliveira, a medição de gravidade da violação aos direitos humanos não está na violência do ato em si, mas "ao grau de repercussão a conduta, em relação à efetiva possibilidade de intervenção da Administração e das autoridades federais para a repressão e prevenção de tais delitos” (OLIVEIRA, 2005, p. 202).

No que se refere à concepção de "direitos humanos", urge destacar que se trata de temática extensa, que não se adequaria a principal proposta deste estudo. Para tanto, importa trazer à baila que a concepção de direitos humanos ultrapassa a institucionalização da política estatal, impondo certa dimensão jusnaturalista, uma vez que são direitos inerentes à personalidade humana independente de reconhecimento do Estado para que sejam validados.

Um conceito recorrente, sustentado por Ingo Sarlet, denota que os direitos humanos são aqueles direitos previstos em textos constitucionais, posto que ao atingirem a consagração na Constituição Federal, passariam a ser considerados como direitos fundamentais (SARLET, 1998, p. 31).

Embora extremamente útil, tal intepretação não pode ser levada à cabo, aplicada de maneira automática, pois se assim fosse, haveria a exclusão do âmbito do incidente de deslocamento de competência todo e qualquer direito assegurado pelo Texto Constitucional de 1988, visto que os direitos humanos se tornariam fundamentais, esvaziando o campo de atuação do deslocamento em questão (CAZETTA, 2009, p. 149).

Luciano Mariz Maia, citado por Ubiratan Cazetta assevera que inexiste exclusividade científica no uso das expressões em cotejo, visto que os direitos humanos já responderam pelo nome de direitos individuais, civis, políticos, liberdades fundamentais, direitos do homem etc, sendo destituído de razão que se considerem como direitos humanos apenas aqueles previstos

\footnotetext{
295 O defensor de direitos humanos e ex-vereador Manoel Mattos foi executado na noite de 24 de janeiro de 2009 , com dois tiros de espingarda calibre 12, no município de Pitimbú, praia de Acaú, litoral sul da Paraíba. Ele foi vereador e denunciava a atuação de grupos de extermínio que teriam assassinado adolescentes, homossexuais e supostos ladrões nos municípios de Pedras de Fogo (PB), Itambé e Timbaúba (PE), na divisa dos dois estados. Quando foi assassinado, Manoel Mattos deveria estar sob proteção policial, conforme entendimento da Comissão Interamericana de Direitos Humanos da Organização dos Estados Americanos (OEA). Suspeita-se que mais de duzentas execuções tenham sido cometidas pelos grupos de extermínio enfrentados publicamente por Manoel Mattos. Por se tratar de caso de grave violação a direitos humanos, entendendo que existiam inúmeros processos e inquéritos arquivados sem algum motivo justificável, a $3^{\text {a }}$ Seção do Superior Tribunal de Justiça decidiu que o crime contra o ex-vereador Manoel Mattos será julgado pela Justiça Federal. O assassinato ocorreu em janeiro de 2009 e a apuração do episódio e do envolvimento de cinco suspeitos ocorreria na Justiça estadual da Paraíba, caso a Procuradoria-Geral da República (PGR) não tivesse pedido a federalização.
} 
em tratados internacionais, e como direitos fundamentais àqueles mesmos direitos integrados na Constituição Federal (MAIA apud CAZETTA, 2009, p. 149).

Contudo, insta consignar que, se não é correto uma leitura estrita sobre os direitos humanos, também não é razoável que se adote um conceito demasiadamente abrangente, como no caso da possibilidade de suscitação do incidente de deslocamento em qualquer persecução criminal.

Para tanto, deve-se buscar um elemento diferencial, um ponto de inflexão que demande a premente necessidade de alteração da competência, derivada da conjugação de várias situações, objetivas e subjetivas, como o contexto em que atuava a vítima, a vinculação da ofensa a uma reiterada atuação estatal ilícita, a uma tentativa de intimidação de minorias ou a prática de crimes internacionalmente reconhecidos como hediondos, rememorando que o Direito Internacional Público possui o chamado "núcleo duro" de direitos que devem ser preservados pela humanidade, tais quais standarts mínimos que constituem a definição de crimes contra a humanidade, ressaltando dentre eles, a escravidão, a execução sumária, as detenções arbitrárias, as discriminações de toda espécie, a tortura, a violência sexual ou contra a mulher e a violência contra aqueles indivíduos considerados mais frágeis, como crianças e idosos (CAZETTA, 2009, p. 151-152).

Nesta seara, se manifestou o Superior Tribunal de Justiça, quando do julgamento do primeiro incidente de deslocamento proposto:

É imprescindível, todavia, verificar o real significado da expressão "grave violação de direitos humanos", tendo em vista que todo homicídio doloso, independente da condição pessoal da vítima e/ou repercussão do fato no cenário nacional ou internacional, representa grave violação ao maior e mais importante de todos os direitos do ser humano, que é o direito à vida (BRASIL, 2005, p. 217)

Assim, o conceito de "grave violação" guarda enorme intimidade com o caso concreto, o qual será analisado sob a égide da proporcionalidade e da razoabilidade, a fim de impedir a banalização do incidente de deslocamento de competência e o esvaziamento da Justiça estadual.

Ademais, pode-se arguir que a definição de graves violações aos direitos humanos será uma tarefa imperativa, mas não subjetiva, diante dos inúmeros parâmetros e normas que possuem ligações com o sistema internacional de proteção destes direitos. Há de ser um crime que viole um bem de proteção jurídica elevada no sistema nacional e internacional, em circunstâncias excepcionais ou que representem práticas sistemáticas de violações a grupos vulneráveis (BARROSO, 2006, p. 40). 
Por todo o exposto, pode-se adentar a um ponto de convergência entre este primeiro requisito e um segundo: a garantia de que o Brasil cumpra as obrigações decorrentes de tratados internacionais de direitos humanos, dos quais seja signatário.

\section{ASSEGURAR O CUMPRIMENTO DE OBRIGAÇÕES INTERNACIONAIS DE DIREITOS HUMANOS}

A Emenda Constitucional no 45/04 também introduziu no ordenamento jurídico pátrio a denominada "constitucionalização dos tratados e convenções internacionais sobre direitos humanos, desde que aprovados pelo quórum qualificado das emendas constitucionais" conforme o artigo $5^{\circ}, \S 3^{\circ}$ da Constituição Federal e ainda, a submissão do Brasil ao Tribunal Penal Internacional, consoante o artigo $5^{\circ}, \S 4^{\circ}$ da Constituição Federal (LENZA, 2009, p.339).

Ademais, o Brasil é signatário de uma série de tratados e convenções internacionais nos quais se compromete a apurar e punir os delitos considerados graves contra os direitos humanos, responsabilizando-se perante cortes e organismos internacionais.

Portanto, a violação em comento deve estar arrolada entre as quais a União tem o dever de reprimir, em decorrência da assinatura de algum tratado internacional. A partir do momento em que o Brasil passa a se submeter ao Tribunal Penal Internacional e a Corte Interamericana de Direitos Humanos, cria-se um rol de possibilidades de responsabilização. Nesta esteira, o segundo requisito para o deslocamento de competência reside justamente nesta possibilidade de responsabilização internacional do Brasil perante os tratados internacionais dos quais seja signatário.

O Procurador-Geral da República assim se manifestou durante o julgamento do IDC $\mathrm{n}^{\mathrm{o}}$ 1:

\footnotetext{
No que diz com a possibilidade de responsabilização internacional decorrente do descumprimento de obrigações assumidas em tratados internacionais, é de se ressaltar que a República brasileira, signatária dos principais atos internacionais de proteção de direitos humanos, responsabiliza-se pelo efetivo cumprimento de tais obrigações, submetendo-se tanto ao sistema global, quanto ao sistema interamericano de direitos humanos, especialmente diante do reconhecimento da jurisdição da Corte Interamericana de Direitos Humanos (BRASIL, 2005, p. 217)
}

Novamente, faz-se necessário a análise de cada caso concreto, a fim de que seja avaliado se os fatos narrados configuram o descumprimento de obrigação internacional, indicando aquela que fora desrespeitada. 
Ainda, Flávia Piovesan e Renato Stanziola Vieira ensinam que há vários casos contra o Brasil pendentes de apreciação na Comissão Interamericana de Direitos Humanos, onde alguns apontam, inclusive, para a responsabilidade direta da União em face da violação dos direitos humanos (PIOVESAN; VIEIRA, 2005, p. 08).

Ressalta-se, por derradeiro, que não se trata de mera presunção de risco da responsabilidade internacional, mas sim de descumprimento explícito de obrigação anteriormente assumida pelo Estado brasileiro.

\section{INÉRCIA OU INCAPACIDADE DAS AUTORIDADES RESPONSÁVEIS DE RESPONDER AO CASO ESPECÍFICO}

A omissão ou demora injustificada na resolução do crime, na sua apuração ou no seu julgamento, é um requisito implícito ao parágrafo $5^{\circ}$ do artigo 109 da Constituição Federal, tendo em vista que não haveria justificativa em deslocar a competência caso o órgão estadual responsável cumprisse adequadamente com seu dever de persecução penal e consequente julgamento.

Tal requisito elucida o caráter subsidiário do deslocamento, no qual, a federalização não pode ser entendida como prima ratio, ou seja, como primeira medida a ser tomada no caso de grave violação a direitos humanos.

Em verdade, o deslocamento de competência é medida excepcional, de caráter subsidiário tal como as demais medidas constitucionais que dispõem sobre conflitos federativos, pois se não as fosse, o legislador teria atribuído a competência diretamente à Justiça Federal. Sendo assim, a competência do Estado federado resta reafirmada, transferindo para o âmbito federal apenas os casos em que o poder estadual não possuir meios efetivos para reprimir e punir a grave violação aos direitos humanos (CAZETTA, 2009, p. 159).

Outrossim, analisando o bojo constitucional voltado à autonomia dos entes federados, a transferência dessa autonomia pela federalização só estará justificada de forma excepcional para preservar um bem maior, nos estritos limites da legalidade.

Insta mencionar que a necessidade de esgotamento dos recursos internos é uma regra geral para que se chegue às cortes internacionais, e desse modo, não poderia ser diferente com o deslocamento de competência ora estudado. 
Vladimir Aras (2005) leciona que a demora injustificada ou a omissão na elucidação do crime é requisito implícito do deslocamento, mormente por inexistir razão para o aludido deslocamento caso os órgãos estaduais estejam cumprindo adequadamente suas funções.

O posicionamento retro encontra-se relativamente pacificado pelo Superior Tribunal de Justiça, através do que preconizou o relator do IDC-1, caso Dorothy Stang ${ }^{296}$ :

\begin{abstract}
Na espécie, as autoridades estaduais encontram-se empenhadas na apuração dos fatos que resultaram na morte da missionária norte-americana Dorothy Stang, com o objetivo de punir os responsáveis, refletindo a intenção de o Estado do Pará dar resposta eficiente à violação do maior e mais importante dos direitos humanos, o que afasta a necessidade de deslocamento da competência originária para a Justiça Federal, de forma subsidiária, sob pena, inclusive, de dificultar o andamento do processo criminal e atrasar o seu desfecho, utilizando-se o instrumento criado pela aludida norma em desfavor de seu fim, que é combater a impunidade dos crimes praticados com grave violação de direitos humanos (BRASIL, 2005, p. 217).
\end{abstract}

Na mesma toada, no julgamento do IDC-2 foi reconhecido pelo Superior Tribunal de Justiça o apelo feito pelas autoridades locais no sentido de serem incapazes de promover a eficiente apuração dos fatos tendo em vista a magnitude da infiltração do crime organizado nas instâncias oficiais.

É notória a incapacidade das instâncias e autoridades locais em oferecer respostas efetivas, reconhecida a limitação e precariedade dos meios por elas próprias. Há quase um pronunciamento uníssono em favor do deslocamento da competência para a Justiça Federal, dentre eles, com especial relevo: o Ministro da Justiça; o Governador do Estado da Paraíba; o Governador de Pernambuco; a Secretaria Executiva de Justiça de Direitos Humanos; a Ordem dos Advogados do Brasil; a Procuradoria-Geral de Justiça do Ministério Público do Estado da Paraíba. As circunstâncias apontam para a necessidade de ações estatais firmes e eficientes, as quais, por muito tempo, as autoridades locais não foram capazes de adotar, até porque a zona limítrofe potencializa as dificuldades de coordenação entre os órgãos dos dois Estados. Mostrase, portanto, oportuno e conveniente a imediata entrega das investigações e do processamento da ação penal em tela aos órgãos federais (BRASIL, 2010).

Assim, a proteção dos direitos básicos não se esgota e nem poderia se esgotar apenas com a atuação dos estados-membros. A intervenção federal no âmbito estadual afigura-se como um reflexo, uma manifestação ou particularização da própria noção de soberania, tendo em

\footnotetext{
${ }^{296}$ A freira Dorothy Stang, de setenta e três anos, chegou ao Brasil em 1966 e desde então passou a atuar na questão de conflitos agrários nas regiões Norte e Nordeste do Brasil, principalmente no que diz respeito ao assentamento de famílias em regiões rurais e na preservação da floresta amazônica. A missionária atuava também em questões sociais, mostrando intensa preocupação na área da educação. Sua atuação foi de encontro aos interesses dos fazendeiros e grileiros da região, o que fez com que por inúmeras vezes a missionária recebesse ameaças de morte. Dentro desta situação, Dorothy Stang procurou a imprensa e as autoridades regionais a fim de pedir proteção, mas não houve qualquer atitude concreta para solucionar o problema, o que acarretou no assassinato da norte-americana em 12 de fevereiro de 2005 no município de Anapu.. O homicídio teve grande repercussão internacional, tendo sido foco da manifestação de diversas organizações não-governamentais, como por exemplo, a ONG Anistia Internacional, que condenou o ocorrido com a missionária norte-americana, afirmando que os governos federal e do Estado do Pará precisam acabar com a violência e com o medo.
} 
mente que o Estado também é expressão de poder interno, possuindo supremacia no âmbito internacional. Por estes motivos, faz-se necessário que a intervenção em comento seja utilizada apenas em última análise, quando não restarem mais alternativas ao estado-membro, ou o mesmo se mostrar ineficaz na persecução que se fizer necessária (CAZETTA, 2009, p. 159).

Fica caracterizado, por derradeiro, que o incidente de deslocamento de competência é medida excepcional de caráter subsidiário, após a comprovação da incapacidade das autoridades locais em combater a grave violência aos direitos humanos.

\section{ARGUMENTOS FAVORÁVEIS À CONSTITUCIONALIDADE DO INCIDENTE}

Os principais argumentos dos defensores da federalização residem justamente em sua função precípua: preservar os direitos consagrados como humanos, coibindo e punindo as graves violações que ensejem uma responsabilização internacional do Brasil.

Por oportuno, faz-se necessário elucidar que o ato de interpretar o texto constitucional não se caracteriza por uma atividade anódina, sem importância, ou ainda de um ato mecânico. Interpretar implica a busca de um sentido, através da qual, serão resguardados uma série de princípios, como bem aduz Eros Grau:

O intérprete produz a norma jurídica não por diletantismo, porem visando a sua aplicação a casos concretos. Interpretamos para aplicar o direito e, ao fazê-lo, não nos limitamos a interpretar os textos normativos, mas também, compreendemos os fatos. A norma jurídica é produzida para ser aplicada a um caso concreto. Essa aplicação se dá mediante a formulação de uma decisão judicial, uma sentença, que expressa a norma da decisão. Aí a distinção entre normas jurídicas e norma de decisão. Esta é definida a partir daquelas (GRAU, 2003, p. 09).

De máxima importância para o correto entendimento dos argumentos favoráveis à constitucionalidade do incidente de deslocamento de competência, é de se destacar o pensamento de Luís Roberto Barroso:

[...] a distinção qualitativa entre regra e princípio é um dos pilares da moderna dogmática constitucional, indispensável para a superação do positivismo legalista, onde as normas se cingiam a regras jurídicas. A Constituição passa a ser encarada como um sistema aberto de princípios e regras, permeável a valores jurídicos suprapositivos, no qual as ideias de justiça e de realização dos direitos fundamentais desempenham um papel central. A mudança de paradigma nessa matéria deve especial tributo à sistematização de Ronald Dworkin. Sua elaboração acerca dos diferentes papéis desempenhados por regras e princípios ganhou curso universal e passou a constituir o conhecimento convencional na matéria. (BARROSO, 2006, p. 30). 
Ainda, o referido autor discorre sobre a valoração dos princípios, vejamos:

\begin{abstract}
Os princípios contêm, normalmente, uma maior carga valorativa, um fundamento ético, uma decisão política relevante, e indicam determinada direção a seguir. Ocorre que, em ordem pluralista, existem outros princípios que abrigam decisões, valores ou fundamentos diversos, por vezes contrapostos. A colisão de princípios, portanto, não só é possível como faz parte da lógica do sistema, que é dialético. Por isso a sua incidência não pode ser posta em termos de tudo ou nada, de validade ou invalidade. Deve-se reconhecer aos princípios uma dimensão de peso ou importância. À visa dos elementos do caso concreto, o intérprete deverá fazer escolhas fundamentadas, quando se defronte com antagonismos inevitáveis, como os que existem entre a liberdade de expressão e o direito de privacidade, a livre iniciativa e a intervenção estatal, o direito de propriedade e a sua função social. A aplicação dos princípios se dá, predominantemente, mediante ponderação (BARROSO, 2006, p. 30).
\end{abstract}

Neste diapasão, se tratando de interpretação constitucional, José Jesus Cazetta Júnior (2004) afirma que a necessária ponderação é aplicável ao caráter constitucionalismo pós-guerra, onde o modelo tradicional de solucionar conflitos entre regras é inútil, tendo em vista que a Constituição não mais consagra valores homogêneos, mas um amplo conteúdo material de princípios de direitos fundamentais, até mesmo contraditórios. Apenas através da ponderação é possível manter a coexistência e a igualdade abstrata entre as normas ou direitos que refletem valores plurais, próprios de uma sociedade heterogênea, mas que pretende manter-se unida em torno da Constituição.

Essa é a situação a qual se encontra a análise do incidente de deslocamento de competência, tendo em vista as supostas violações a determinados princípios constitucionais, como do juiz natural e do duplo grau de jurisdição. Essa contradição aparente enriquece o debate e permite uma melhor compreensão dos interesses colocados em pauta, desempenhando papel eminentemente dialético.

Não obstante, é inegável que não existem direitos fundamentais ilimitados, como afirmou o Supremo Tribunal Federal, veja-se:

[...] os direitos e garantias individuais não tem caráter absoluto. Não há, no sistema constitucional brasileiro, direitos ou garantias que se revista de caráter absoluto, mesmo porque razoes de relevante interesse público ou exigências derivadas do princípio de convivência das liberdades legitimam, ainda que excepcionalmente, a adoção, por parte dos órgãos estatais, de medidas restritivas das prerrogativas individuais ou coletivas, desde que respeitados os termos estabelecidos pela própria Constituição. O estatuto constitucional das liberdades públicas, ao delinear o regime jurídico a que estas estão sujeitas - e considerando o substrato ético que as informa - permite que sobre elas incidam limitações de ordem jurídica, destinadas de um lado, a proteger a integridade do interesse social e, de outro, a assegurar a coexistência harmoniosa das liberdades, pois nenhum direito ou garantia pode ser exercido em detrimento da ordem pública ou com desrespeito aos direitos e garantias de terceiros (BRASIL, 2000, p. 20). 
Em se tratando de conflito entre princípios constitucionais, sobre os quais não se podem aplicar as regras da hierarquia das normas (lei superior prevalece sobre inferior); da cronologia (lei posterior revoga anterior) ou da especialização (lei específica prevalece sobre lei geral), Luís Roberto Barroso ensina:

[...] a denominada ponderação de valores ou ponderação de interesse é a técnica pela qual se procura estabelecer o peso relativo de cada um dos princípios contrapostos. Como não existe um critério abstrato que imponha a supremacia de um sobre o outro, deve-se, à vista do caso concreto, fazer concessões recíprocas, de modo a produzir um resultado socialmente desejável, sacrificando o mínimo de cada um dos princípios ou direitos fundamentais em oposição. $O$ legislador não pode, arbitrariamente, escolher um dos interesses em jogo e anular o outro, sob pena de violar o texto constitucional. Seus balizamentos devem ser o princípio da razoabilidade e a preservação, tanto quanto possível, do núcleo mínimo do valor que esteja cedendo passo. Não há aqui, superioridade formal de nenhum dos princípios em tensão, mas a simples determinação da solução que melhor atende o ideário constitucional na situação apreciada (BARROSO, 2006, p. 30).

Por conseguinte, para a análise da constitucionalidade da federalização em cotejo, interessa analisá-la sob a égide dos princípios da razoabilidade e da proporcionalidade. Nesta toada, explicitam Barcellos e Barroso:

O princípio da razoabilidade ou da proporcionalidade [...] não está expresso na Constituição, mas tem seu fundamento nas ideias de devido processo legal substantivo e na de justiça Trata-se de um valioso instrumento de proteção dos direitos fundamentais e do interesse público, por permitir o controle da discricionariedade dos atos do Poder Público e por funcionar como a medida com que a norma deve ser interpretada no caso concreto para a melhor realização do fim constitucional nela embutido ou decorrente do sistema. Em resumo sumário, o princípio da razoabilidade permite ao Judiciário invalidar atos legislativos ou administrativos quando: a) não haja adequação entre o fim perseguido e o instrumento empregado (adequação) b) a medida não seja exigível ou necessária, havendo meio alternativo menos gravoso para chegar ao mesmo resultado (necessidade/vedação do excesso) e c) não haja proporcionalidade em sentido estrito, ou seja, o que se perde com a medida é de maior relevo do que aquilo que se ganha (proporcionalidade em sentido estrito). O princípio pode operar, também, no sentido de permitir que o juiz gradue o peso da norma, em uma determinada incidência, de modo a não permitir que ela produza um resultado indesejado pelo sistema, assim fazendo a justiça do caso concreto (BARCELLOS; BARROSO, 2006, p. 362-363).

É possível reconhecer que a compatibilidade do incidente de deslocamento de competência somente acontecerá se este instituto atender ao princípio da razoabilidade, passando pela adequação ao caso concreto, pela necessidade de utilização deste meio, pela vedação ao excesso e pela proporcionalidade em sentido estrito. Muito embora a comprovação destas adequações esteja diluída pelo trabalho, é possível justificá-los sucintamente adiante.

Para que se possa identificar a adequação, faz-se necessário aferir qual o fim perseguido e o instrumento que será empregado para tanto. O incidente de deslocamento de competência possui como objetivo a criação de um instrumento que permita uma ampliação qualitativa da 
proteção dos direitos humanos, agindo como meio eficaz para realizar diretamente a resposta judicial aos casos de grave violação dos compromissos internacionais assumidos pelo Brasil.

Objetivando alcançar tal intento, criou-se um instrumento que, respeitando o modelo federal do Estado brasileiro, atribuiu a um tribunal superior, já responsável pela defesa e pela uniformização da ordem infraconstitucional, a missão de identificar os casos concretos em que haja efetiva necessidade de intervenção do ente federal. Concebeu-se, portanto, um mecanismo cuidadoso que envolve a manifestação fundamentada, em processo judicial, e que terá por resultado a redistribuição do feito a um juízo previamente reconhecível, dotado de todas as garantias institucionais típicas do Poder Judiciário e do Ministério Público (CAZETTA, 2009, p. 92).

Não pairam dúvidas de que o fim almejado encontra abrigo em uma sociedade que preza pelo princípio da dignidade da pessoa humana como um de seus fundamentos e na prevalência dos direitos humanos. Outrossim, o referido instrumento preserva a entidade federativa, salvaguardando a noção de devido processo legal, garantindo a adequação da federalização.

Ademais, não parece restar questionamento de que o incidente de deslocamento é uma medida exigível, uma vez que o Estado brasileiro poderá ser responsabilizado internacionalmente pelas obrigações assumidas. Afora outros casos de relevância, basta rememorar que o Brasil já fora condenado pela Corte Interamericana de Direitos Humanos pelo caso "Ximenes Lopes", além de sofrer medidas provisionais adotadas no caso da Penitenciária "Urso Branco" 297 e do tratamento degradante nas unidades da FEBEM em São Paulo.

A federalização é, pois, medida exigível diante da necessidade da concretização dos direitos humanos, em contraposição a uma realidade muito distante do ideal, com reiteradas situações de desrespeito aos direitos mais fundamentais do ser humano. Implica, por oportuno, averiguar se existe meio menos gravoso ou alternativo ao incidente de deslocamento de competência.

Neste diapasão, Ubiratan Cazzeta leciona que:

O IDC não é instrumento redentor, que trará, sozinho, a solução para o problema da violação dos direitos humanos. Todavia, não é, tampouco, um mecanismo autoritário ou abusivo, como se pretendeu configurá-lo nas críticas; aliado a um ampla teia de

\footnotetext{
${ }^{297}$ Trata-se da chacina que ocorreu nas dependências da penitenciária Urso Branco, no estado de Rondônia, após a tentativa de fuga em massa, onde alguns dos 1,3 mil presos teriam assassinados outros 27 detentos. O caso é o maior massacre de presos do país depois do Carandiru, e ganhou repercussão internacional pela brutalidade dos assassinatos, que envolveram até decapitação, choque elétrico, e enforcamento. Em 2004, o Ministério Público ofereceu denúncia contra 44 presos e 6 agentes públicos: o então diretor geral do presídio, o ex-diretor de segurança, o ex-Superintendente de Assuntos Penitenciários e o ex-gerente do sistema penitenciário de Rondônia, além de dois oficiais da Polícia Militar do estado.
} 
atuações estatais, poderá, sim, vir a ser um instrumento eficaz para romper situações concretas de desrespeito aos direitos humanos (CAZETTA, 2009, p. 93-94).

No que se refere aos ganhos decorrentes da medida, é patente que se configuram como maiores do que as eventuais perdas de que se pode cogitar, pois o incidente preserva os contornos do federalismo, assegura o juízo natural, sem ofender o devido processo legal, garante a ampla defesa e se configura por importante aparato para manter alerta os estadosmembros.

Nesse comenos, o primeiro argumento balizador da constitucionalidade do instituto reside no término da conjectura paradoxal onde o Estado brasileiro é responsabilizado pelo descumprimento das obrigações internacionais na pessoa jurídica da União, de forma única e exclusiva, sem que a mesma tivesse a possibilidade de chamar para si tal responsabilidade, investigando, processando ou julgando os crimes que ensejaram sua punição.

Pedro Lenza (2011) ressalta que a previsão estabelecida no artigo 109, V-A e no $\S 5^{\circ}$ do mesmo artigo da Constituição Federal fora muito bem vindo e acertado no sentido de adequar o funcionamento do Judiciário brasileiro ao sistema de proteção internacional dos direitos humanos, destacando ainda que a União é que será responsabilizada em nome do Estado brasileiro, por aquilo que fora acordado em tratados internacionais. Outrossim, havendo descumprimento ou afronta a direitos resguardados pelos referidos tratados, a União não poderá invocar a cláusula federativa para se eximir das responsabilidades assumidas perante os órgãos internacionais.

No mesmo sentido, Flávia Piovesan ressalta que a federalização será importante instrumento na concretização e realização dos direitos humanos, quando os mesmos padeçam de graves violações, primando por um Estado Democrático de Direito, consoante o disposto no artigo $1^{\mathrm{o}}$ da Constituição Federal, salientando ainda:

Se qualquer Estado Democrático pressupõe o respeito dos direitos humanos e requer a eficiente resposta estatal quando de sua violação, a proposta de federalização reflete sobretudo a esperança de que a justiça seja feita e os direitos humanos respeitados (PIOVESAN, 2005, p. 42).

Outro argumento que consolida a constitucionalidade do incidente de deslocamento reside na possibilidade de dotar o sistema jurisdicional de melhores instrumentos para enfrentar a impunidade e a afronta à ordem jurídica, em casos quem envolvam as já badaladas graves violações aos direitos humanos, fato que muitas vezes não ocorre nos órgãos estaduais. Trazendo à baila sua experiência defronte as Cortes Internacionais, Francisco Rezek aduz: 
Em geral, nas federações os crimes dessa natureza, os crimes previstos por qualquer motivo em textos internacionais, são crimes federais e da competência do sistema federal de Justiça. Isso tem várias vantagens, como uma jurisprudência uniforme, uma jurisprudência unida, a não tomada de caminhos diversos segundo a unidade da federação em que se processe o crime. É vantajoso e é praticado em outras federações (REZEK, 2002, p. 150).

Ademais, é cediço que o estado brasileiro já se mostrou por vezes ineficaz e inoperante na persecução e julgamento de crimes de grande repercussão internacional, como no caso do massacre de Eldorado dos Carajás e a chacina da Candelária. Ressalta-se que ambos os casos foram marcados pela influencia negativa de agentes estatais, incluindo a presença de policiais no banco dos réus. A então Relatora das Nações Unidas sobre Execuções Sumárias, Arbitrárias e Extrajudiciais, Asma Jahangir, identificou a Emenda Constitucional 45/2004 como "um passo bem-vindo para combater a impunidade" (GAJOP. 2010, p. 28).

Paulo Bonavides (2010) atesta que o incidente de deslocamento de competência visa preservar os mais altos valores protegidos pela Constituição Federal, sem que com isso as demais cláusulas pétreas sejam prejudicadas, pois inexiste direito absoluto, que não possa ser relativizado diante do choque com outro direito normatizado e de mesma força hierárquica. Para tanto, faz-se necessário o uso do princípio da proporcionalidade, mais elástico que os demais, protegendo o cidadão contra excessos do Estado e defendendo as liberdades constitucionais.

Entrementes, para a real eficácia do incidente em estudo, faz se necessário que o mesmo esteja balizado pelo princípio da proporcionalidade, com fito de que tal instituto não se torne uma medida banalizada, fugindo de seu escopo principal. Segundo Gilmar Mendes, citado por Jorge Assaf Maluly:

\begin{abstract}
A proporcionalidade se dá quando verificada restrição a determinado direito fundamental ou a um conflito entre distintos princípios constitucionais de modo a exigir que se estabeleça o peso relativo de cada um dos direitos por meio da aplicação das máximas que integram o mencionado princípio da proporcionalidade. São três as máximas parciais do princípio da proporcionalidade: a adequação, a necessidade e a proporcionalidade em sentido estrito. Há de perquirir-se na aplicação do princípio da proporcionalidade, se em face do conflito entre os dois bens constitucionais contrapostos, o ato impugnado afigura-se adequado (isto é, apto para produzir o resultado desejado), necessário (isto é, insubstituível por outro meio menos gravoso e igualmente eficaz) e proporcional em sentido estrito (ou seja, se estabelece uma relação ponderada entre o grau de restrição de um princípio e o grau de realização do princípio contraposto) (MENDES apud MALULY, 2005, p. 06).
\end{abstract}

Note-se que o incidente de deslocamento de competência não chega a subtrair nenhuma competência originária dos estados, tampouco se apresenta como uma violação ao pacto federativo, tendo em vista sua natureza subsidiária e mediante a comprovação da incapacidade do estado-membro em investigar, processar ou julgar o acontecido. Neste mesmo sentido, 
assim se manifestou o Ministro Arnaldo Esteves Lima quando do julgamento do primeiro incidente de deslocamento de competência:

\begin{abstract}
O deslocamento de competência - em que a existência de crime praticado com grave violação aos direitos humanos é pressuposto de admissibilidade do pedido - deve atender ao princípio da proporcionalidade (adequação, necessidade e proporcionalidade em sentido estrito), compreendido na demonstração concreta de risco de descumprimento de obrigações decorrentes de tratados internacionais firmados pelo Brasil, resultante da inércia, negligência, falta de vontade política ou de condições reais do Estado-membro, por suas instituições, em proceder à devida persecução penal (BRASIL, 2005, p. 217).
\end{abstract}

Trata-se, pois, de uma garantia constitucional de eficácia plena, com caráter eminentemente instrumental, possibilitando o deslocamento da competência, de forma horizontal, da Justiça Estadual para a Justiça Federal, pois ambas compõe uma só Justiça, um só sistema judiciário brasileiro. Assim, embora não seja contemporâneo à Emenda Constitucional 45, o ilustre magistério de João Mendes Júnior, datado de 1916 ainda sobrevive ao tempo, servindo como base para o presente estudo:

\footnotetext{
O Poder Judiciário, delegação da soberania nacional, implica a idéia de unidade e totalidade da força, que são as notas características da idéia de soberania. O Poder Judiciário, em suma, quer pelos juízes da União, quer pelos juízes dos estados, aplica leis nacionais para garantir os direitos individuais; o Poder Judiciário não é federal, nem estadual, é eminentemente nacional, quer se manifestando nas jurisdições estaduais, quer se aplicando ao cível, quer se aplicando ao crime, quer decidindo em superior, quer decidindo em inferior instância (MENDES JR., 1916).
}

A advertência de ontem há de ser o farol de hoje, pois o Brasil não é um país de tradição cujos estados-membros são fortes individualmente. O papel central da União na manutenção da cidadania é uma realidade que não se pode olvidar (CAZETTA, 2009, p. 98).

Destaca-se que o deslocamento de competência está inserido em um sistema de federalismo considerado cooperativo, nascido a partir da crise do Estado Liberal clássico, onde a União foi adquirindo ainda mais competências, repassando algumas aos seus estadosmembros.

A cooperação de competências jurisdicionais é necessária sempre que determinado ente da federação não possuir condições para cumprir as prescrições constitucionais, seja por negligência, por inércia, ou por falta de vontade dos governantes. Reitera-se que quando o poder local não conseguir desempenhar suas tarefas, caberá à União, subsidiariamente, assumi-las (CAZETTA, 2009, p. 98).

A federalização dos crimes constitui regra de modificação de competência interna com base constitucional e subsidiária, no sentido de complementar a competência residual da justiça estadual e não de suprimi-la. Analisando as competências delimitadas pela Constituição de 1988 
há, de modo geral, um favorecimento às competências concorrentes, no sentido de que exista um federalismo cooperativo, com os olhos voltados mais para a colaboração de seus estadosmembros do que com a independência total.

É justamente embasado nessa colaboração de tarefas que o legislador constitucional previu a possibilidade de intervenção federal, consoante o artigo 34 da Constituição Federal. Ademais, tal medida possui caráter mais drástico, possuindo como um dos fundamentos, a proteção dos direitos humanos, conforme alínea $b$, inciso VII do artigo em comento.

Luiz Alberto David Araújo e Vidal Serrano Nunes Júnior (2005), analisando o instituto da intervenção federal, dissertam que "o Estado Federal deve conter um dispositivo de segurança, necessário à sua sobrevivência. Esse dispositivo constitui, na realidade, uma forma de mantença do federalismo diante de graves ameaças”.

Ora, se é possível tal medida drástica para assegurar os direitos da pessoa humana, não há de se falar em inconstitucionalidade ao realizar uma intervenção considerada pontual, apenas em relação à determinado caso concreto.

Por derradeiro, insta salientar acerca da decisão do Superior Tribunal de Justiça quando do julgamento do IDC-1, porquanto as preliminares de inépcia da inicial e de que o dispositivo seria uma norma de eficácia contida, carecendo de um rol definidor e exemplificativo dos crimes considerados graves, foram rejeitadas de plano, restando patente que "não há incompatibilidade do incidente de deslocamento de competência com qualquer outro principio constitucional ou com a sistemática processual em vigor” (BRASIL, 2005, p. 217).

Arrematando a temática, leciona Alexandre de Moraes:

\begin{abstract}
As justiças especializadas no Brasil não podem ser consideradas justiças de exceção, pois são devidamente constituídas e organizadas pela própria Constituição Federal e demais leis de organização judiciária. Portanto, a proibição de existência de tribunais de exceção não abrange a justiça especializada, que é atribuição e divisão da atividade jurisdicional do Estado entre vários órgãos do Poder Judiciário (MORAES, 2002, p. 109).
\end{abstract}

Importante destacar que a federalização dos crimes graves contra os direitos humanos reafirmou a competência dos órgãos estaduais para apuração e julgamento dos mesmos, disponibilizando apenas, um instrumento subsidiário e extraordinário para ser aplicado quando houver incapacidade do órgão estadual em cumprir com as obrigações assumidas internacionalmente pela União. Outrossim, haverá sempre a possibilidade de não haver o deslocamento, desde que a Justiça Estadual atue de forma competente diante da grave violação ocorrida. 


\section{CONSIDERAÇÕES FINAIS}

Inicialmente, convém destacar que para o Estado brasileiro, se mostra essencial o papel da Comissão Interamericana de Direitos Humanos e da Corte Interamericana de Direitos Humanos, responsáveis por averiguar a responsabilidade do Brasil em decorrência da omissão ou ação de atos por agentes estatais que violem os direitos humanos.

A presente possibilidade de responsabilização, corroborando com a expressa aceitação do Brasil à jurisdição da Corte Interamericana de Direitos Humanos, implica em um novo modo de agir em relação aos atos externos, incorporando ao cotidiano nacional o respeito às obrigações internacionalmente assumidas. Submetem a este crivo, os atos dos Três Poderes, não importando na seara internacional, como se organiza o Estado, pois o mesmo é considerado uno e indivisível não podendo utilizar suas dissonâncias para fugir do compromisso assumido internacionalmente. Neste diapasão. É patente que o compromisso externo, mesmo que indiretamente, reforça o compromisso interno, pois a atuação internacional requer a insuficiência dos meios internos, impondo um esgotamento dos recursos locais de proteção aos direitos humanos. Tal esgotamento representa o reconhecimento de que a instância internacional somente deve atuar após ter dado ao Estado a chance de fazer valer suas regras internas, coibindo e corrigindo as graves violações aos direitos humanos.

Neste diapasão, a possibilidade de deslocamento de competência introduzida pela Emenda Constitucional $n^{\circ} 45$ recebeu diversas críticas, as quais sustentavam ofensas a determinados princípios constitucionais. Tais ponderações evocam dois alertas importantes: o primeiro se refere ao excesso de críticas pelo uso de expressões indeterminadas; o segundo se faz necessário pelo suposto entendimento de que os princípios do juiz natural, do pacto federativo e do devido processo legal teriam um grau de proteção que inviabilizaria uma nova leitura no sistema constitucional, pautada pela razoabilidade e pela proporcionalidade. Contudo, ressalta-se que os conceitos indeterminados, por vezes tão criticados, visam garantir que o texto constitucional seja maleável ao avanço social.

Por todo o exposto, é hialino que não há violação ao princípio do pacto federativo, uma vez que o federalismo contemporâneo busca um modelo de cooperação entre seus entes, relembrando que a União é que será responsabilizada internamente pelas violações que forem praticadas dentro de seus estados-membros.

Não se verifica, também, qualquer violação ao princípio do juiz natural, eis que não há a criação de um juízo de exceção, mas sim, a possibilidade de deslocamento para um Tribunal 
previamente conhecido. Ademais, o princípio do juiz natural visa garantir um julgamento imparcial dentro das regras previamente conhecidas. Ora, mesmo com o deslocamento para a Justiça Federal, não há de se falar em julgamento parcial, tampouco em ofensa à legislação pátria em vigor. O que se verifica é apenas uma redistribuição da competência por critérios assumidos previamente pela Constituição Federal.

No que atine ao devido processo legal e a ampla defesa, tais princípios estarão resguardados diante da suscitação do incidente de deslocamento, tendo em vista que o requerido ou investigado terá interesse legítimo a ser defendido e deverá ser ouvido pelo Superior Tribunal de Justiça.

Por conseguinte, o uso da expressão "grave violações aos direitos humanos", considerada por alguns como genérica em demasia, não se diferencia de tantos outros conceitos indeterminados presentes no texto Constitucional, pois a Constituição Federal empregou um termo cujo conteúdo deverá ser analisado diante do caso concreto, evitando seu uso indiscriminado, mas assegurando a sua utilidade. Destarte, analisando a constitucionalidade da federalização, deve-se ater ao seu elemento diferencial, o ponto de inflexão que demande a extraordinária necessidade de alteração de competência.

Verificou-se que o incidente de deslocamento de competência se baseia em três sustentáculos, três requisitos: a identificação da grave violação aos direitos humanos; o compromisso internacional assumido; a incapacidade do estado-membro em oferecer resposta oportuna e adequada. Assim sendo, não se trata de medida banal, vez que para o efetivo deslocamento é imperioso que os aludidos requisitos coexistam no caso concreto.

Não sem razão, pode-se realizar uma comparação do incidente de deslocamento a um sistema de freios e contrapesos, onde o controle recíproco acaba por induzir atuações preventivas, que evitam a ocorrência do ilícito. A mera possibilidade de deslocamento tem o condão de forçar o estado-membro a adotar medidas efetivas, visando evitar a perda da competência.

Nesse comentos, impende salientar que o instituto em análise não tem o escopo de ser um instrumento salvacionista de todos os problemas do judiciário brasileiro. Não serão a Justiça Federal, a Policia Federal e o Ministério Público Federal que irão acabar com a crescente impunidade no Brasil. É cediço que os estados-membros possuem plena capacidade para investigarem e julgarem os casos de graves violações aos direitos humanos, sendo inegável que têm juízes capacitados, policiais preparados e promotores atuantes. Entrementes, toda regra possui sua exceção, e a experiência concreta do país demonstra que a transferência para a Justiça 
Federal é recomendada face à impunidade, à excessiva demora e ao envolvimento de agentes estatais nos crimes.

Por derradeiro, é oportuno que o incidente de deslocamento de competência seja considerado como um instrumento de fortalecimento dos esforços conjuntos dos estadosmembros e da União, na busca incessante e essencial para a concretização dos direitos assegurados pela Constituição, tornando realidade o ideal preconizado como dignidade da pessoa humana em seu mais amplo escopo, não permitindo a banalização ou vulgarização o incidente, devendo ser utilizado apenas quando não houver no plano local, meios hábeis ou eficazes para a apuração, persecução e processamento de graves crimes contra os direitos mais básicos do ser humano.

\section{REFERÊNCIAS}

ARAS, Vladimir. Direitos humanos: federalização de crimes só é válida em último caso. Revista Consultor Jurídico, maio 2005. Disponível em: <http://conjur.estadao.com.br/static/text/34833,1>. Acesso em: 21 jul.2015.

ARAUJO, Luiz Alberto David. NUNES JÚNIOR, Vidal Serrano. Curso de direito constitucional, $9^{\mathrm{a}}$ ed. São Paulo: Saraiva, 2005.

BARCELLOS, Ana Paula de; BARROSO, Luís Roberto. O começo da história: a nova interpretação constitucional e o papel dos princípios no direito brasileiro. 2 . ed. Rio de Janeiro: Renovar, 2006.

BARROSO, Luís Roberto. A nova interpretação constitucional: ponderação, direitos fundamentais e relações privadas. 2. ed. Rio de Janeiro: Renovar, 2006.

BONAVIDES, Paulo. Curso de direito constitucional. 10 10 ed. São Paulo: Malheiros, 2010.

BRASIL. Constituição (1988). Constituição da República Federativa do Brasil. Disponível em: < http://www.planalto.gov.br/ccivil_03/constituicao/constituicao.htm>. Acesso em: 10 jul. 2013.

BRASIL. Proposta de Emenda Constitucional $n^{\circ}$ 96/1992. Introduz modificações na $\begin{array}{llllll}\text { estrutura do } & \text { Poder } & \text { Judiciário. } & \text { Disponível }\end{array}$ http://www.camara.gov.br/proposicoesWeb/fichadetramitacao?idProposicao=14373>. Acesso em: 12.jul. 2015 
. Superior Tribunal de Justiça. $3^{\text {a }}$ Seção. IDC no 01. Ementa: [...] Relator: Arnaldo Esteves Lima. Brasília, DF, 08 jun. 05. DJ de 10.10.05, p. 217.

Superior Tribunal de Justiça. Incidente de Deslocamento de Competência $\mathbf{n}^{\mathbf{0}} \mathbf{2}$ DF. Relator a Laurita Vaz. Brasília, 27 out. 2010.

CASTRO, Flávio Dino de; SCHREIBER, Simone. Federalização da competência para julgamento de crimes contra os direitos humanos. Disponível em: $<$ http//www.ajufe.org.br/index.php?ID_MATERIA=389>. Acesso em: 27 ago. 2015

CAZETTA, Ubiratan. Direitos humanos e federalismo: o incidente de deslocamento de competência. São Paulo: Atlas, 2009.

CAZETTA JUNIOR, José Jesus. A ineficácia do precedente no sistema brasileiro de jurisdição constitucional. 2004. 203 f. Tese (Doutorado em Direito). Faculdade de Direito, Universidade de São Paulo, São Paulo: 2004.

FERNANDES, Antônio Scarance. Processo Penal Constitucional. São Paulo: RT, 2010.

GAJOP, Gabinete de Assessoria Jurídica às organizações populares. Direitos Humanos Internacionais: construção de bases para o monitoramento das recomendações da $\mathrm{ONU}$ ao Brasil. Recife: Dhinternacional, 2010.

GRAU, Eros. Ensaio e discurso sobre a interpretação/aplicação do direito. 2. ed. São Paulo: Malheiros, 2003.

LENZA, Pedro. Direito Constitucional Esquematizado. 13. ed. São Paulo: Saraiva, 2009.

MALULY, Jorge Assaf. A Federalização da competência para julgamento dos crimes praticados contra os Direitos Humanos. Boletim IBCCRIM, São Paulo, v. 12, nº 148, p. 4-6, mar. 2005.

MARQUES, José Frederico. Da competência em matéria penal. São Paulo: Millennium, 2000.

MENDES JÚNIOR. João. Reflexão: O Poder Judiciário por João Mendes Júnior. Disponível em: <http://assetj.jusbrasil.com.br/noticias/2991556/reflexao-o-poder-judiciariopor-joao-mendes-jr>. Acesso em: 17 ago. 2015. 
MORAES, Alexandre. Direito Constitucional. 12. ed. São Paulo: Atlas, 2002.

OLIVEIRA, Eugênio Pacelli de. Curso de Processo Penal - Incluindo Reforma do Judiciário. $4^{\text {a }}$ ed. Belo Horizonte: Del Rey, 2005.

PIOVESAN, Flavia. Direitos Humanos e o princípio da Dignidade Humana. In: PAULA, Alexandre Sturion de. (Coord.). Ensaios Constitucionais de Direitos Fundamentais. Campinas: Servanda, 2006.

. Direitos humanos e o princípio da dignidade humana. Revista do Advogado, São Paulo, v. 23, n 70, p. 34-42, jul. 2003.

federalização.

Direitos humanos internacionais e jurisdição supra-nacional: a exigência da http://www.dhnet.org.br/direitos/militantes/flaviapiovesan/piovesan_federalizacao.html>. Acesso em: 18 jul. 2013.

PIOVESAN, Flávia. VIEIRA, Renato Stanziola. Federalização dos crimes contra os direitos humanos: o que temer? Boletim IBCCRIM, São Paulo, v. 13, n. 150, p. 8-9, mai. 2005.

RAMOS, André de Carvalho. Reflexões sobre as vitórias do caso Damião Ximenes. Revista Consultor Jurídico, 8 de setembro de 2006. Disponível em: <http://www.conjur.com.br/2006set-08/reflexoes_vitorias_damiao_ximenes>. Acesso em: 05 ago. 2013.

REZEK, José Francisco. Direito internacional Público: curso elementar. 9. ed. rev. São Paulo: Saraiva, 2002.

SARLET, Ingo Wolfgang. A eficácia dos direitos fundamentais. 6. ed., Porto Alegre: Livraria do Advogado, 2006.

\section{APPLICABILITY OF RACING SHIFTING INCIDENT}

\section{ABSTRACT}

The Constitutional Amendment 45 / 04 created a new legal institute, called the incident displacement of jurisdiction, applicable in cases of 
serious human rights violations, allowing for the transfer of the investigation or the lawsuit to federal authorities. This creation led to major doctrinal discussions, due to an apparent violation of some constitutional principles, as the natural judge, the contradictory, the legal defense, the federal pact and legal certainty. The scope of the present paper was to examine the constitutionality of the incident displacement of competence, adapting it to the national legal system through the principles of reasonableness and proportionality, bringing up some lessons about international mechanisms of human rights protection and analogies to the federalization through specific cases, such incidents raised to date, striving for its applicability in the national legal system.

Keywords: Incident. Displacement of competence. Human rights. Federalism. Constitutional principles. Immutable clauses. Proportionality. 